\title{
Reproducing the Gender Order in the Wake of Disasters. Revisiting a Case Study on a Mudslide Disaster in Austria
}

\author{
Sandra Maria Pfister*
}

\begin{abstract}
While disasters are considered a rupture of the established gender order, they rarely result in its profound change. This paper contributes to a proper understanding of its perpetuation. It suggests to take a disaster as a framework for action that is symbolically shaped by gender expectations. Within this framework, the gender order is reproduced through practices that affirm and reinforce these expectations and, thus, impede the gender-neutralising potential of a practical deviation from these expectations. This is illustrated by revisiting 20 guided interviews from a case study on a mudslide disaster in Austria.
\end{abstract}

Keywords: Gender order, doing gender, undoing gender, gendered disaster experience

\section{Zur Reproduktion der Geschlechterordnung durch Katastrophen. Erkenntnisse einer Fallstudie zu einem Murenabgang in Österreich}

Zusammenfassung: Trotz ihres erschütternden Charakters brechen Katastrophen nur selten mit der bestehenden Geschlechterordnung. Der Beitrag rückt die Reproduktion der Geschlechterordnung in der Katastrophe in den Fokus. Katastrophen werden als situativer Handlungsrahmen verstanden, der symbolisch durch geschlechtsspezifische Erwartungen begrenzt ist und Praktiken hervorbringt, die diese Erwartungen bestätigen und verstärken. Zur Illustration werden 20 leitfadengestützte Interviews zu einem Murenabgang in Österreich einer Sekundärdatenanalyse unterzogen.

Schlüsselwörter: Geschlechterordnung, Doing Gender, Undoing Gender, geschlechtsspezifische Katastrophenerfahrung

\section{La reproduction des rapports de genre par les catastrophes. Résultats d'une étude de cas sur un glissement de terrain en Autriche}

Résumé: Si les catastrophes sont considérées comme une rupture du rapport de genre établi, elles entraînent rarement un changement en sa faveur. Ce document contribue à une bonne compréhension de sa perpétuation. Il suggère de prendre une catastrophe comme cadre d'action qui est symboliquement façonnée par les attentes des hommes et des femmes. Le rapport de genre est reproduit par des pratiques qui affirment et renforcent ces attentes et empêchent le potentiel de neutralisation des genres d'une simple déviation. Pour illustrer cela, 20 interviews guidées sur un glissement de terrain en Autriche sont soumises à une nouvelle analyse. Mots-clés: Rapport de genre, Doing Gender, Undoing gender, expérience genrée des catastrophes

Johannes-Kepler University, Institute of Social Politics and Policy, A-4040 Linz, sandra.pfister@ jku.at 
What constitutes a disaster is contested (Quarantelli 1998). While early scholars emphasised differences across disaster agents, soon, the disaster was recognised as a social phenomenon (e.g., Gilbert 1998) and disaster scholars fairly agreed that disasters are a disruption of the taken-for-granted order of everyday life (Clausen 1994; Stallings 1998). As a result, disasters are often considered to provide a window of opportunity for change of the established social order (Boin et al. 2009; Pelling and Dill 2010), affecting the gender order as well (Bradshaw 2015; Fothergill 1999). But still, empirical research suggests a resistance of the social order against disasters (Dombrowsky 1989; Quarantelli 2003), and feminist disaster scholars have observed a perpetuation, or even exaggeration, of the pre-existing gender patterns as well (Always and Smith 1998; e.g., Horton 2012; Pacholok 2013; Bradshaw 2014; Austin 2015; Bradshaw 2015). In other words, the potential rupture of the established gender order rarely translates into a profound change. This raises the often neglected question of how the established gender order is reproduced in the wake of disasters. While it is widely accepted that the gender differences in disaster experience stems from the pre-disaster gender order, the disaster itself has hardly been addressed as a site of reproduction of the gender order. This paper contributes to a proper understanding of the perpetuation of the gender order by building on the well-known assumption that the gender order is permanently reproduced by the doing of gendered actors.

Initially, the paper gives an overview of how disasters have been recognised and discussed as gendered sites in the literature (2). Then it develops the conceptual framework to take disasters as sites for action that are symbolically limited by gender expectations (3). Finally, the paper refers back to a previous case study of a mudslide disaster in Austria (4). After providing some context information on the disaster setting (5), it shows how gender expectations informed the doing of gendered actors as well as its perception, which it argues to be a key mechanism for the perpetuation of the gender order (6). Finally it ends with a short discussion (7).

\section{Disasters as Highly Gendered Sites}

A disaster in itself is "a highly gendered social event" (Enarson 2006). By now, this is a well-known fact. Nevertheless, disaster research used to be fairly gender-blind (Tierney 2012; Enarson and Pease 2015; Villarreal and Meyer 2020). However, disaster scholars have early observed dramatic gender differences in the disaster experience such as the impacts (2.1) and disaster-related activities (2.2). By now, it is widely accepted that these stem from the pre-disaster gender order, leading disaster scholars to promote a link to general feminist literature (Fothergill 1998; 
Enarson and Phillips 2008). Nevertheless, disasters have also been considered to bear moments of deviation and as ruptures of established power relations (2.3), and, more recently, as crises of masculinity (2.4).

\subsection{Gender Differences in Vulnerability}

Early observations of women's extensive burdens due to disaster impacts triggered the emergence of a first strand of explicit gender disaster research focusing on differences in vulnerability between men and women (Enarson and Meyreles 2004; Tierney 2012; Gaillard et al. 2017; Enarson et al. 2018). While the dualistic view on gender itself has recently been suggested as a source of vulnerability and amplification of human suffering, as it may neglect the actual needs and realities of disaster victims (Gaillard et al. 2017), it is still deeply anchored in the social reality.

Still, women are often found to be more vulnerable to disasters (Oxfam 2005; Neumayer and Plümper 2007; Tierney 2019). This is far away from being a result of their "female nature". Rather, it is the social production of the pervasive gender inequality of social reality, regarding the social status, norms and expectations. To put it simple, women are "made more vulnerable" (Richter and Flowers 2010, 209). E. g., women are disproportionally affected by poverty and still are disadvantaged in the labour market. This limits their access to resources (Lewis 1997; Enarson 2001; Esping-Andersen 2002; Orloff 2009; Lister 2010; Richter and Flowers 2010), makes them dependent on the benevolence of others, hence increase their risk of insecurity (Pateman 2006; Bradshaw 2014), and limits their decision-making power within families during disaster times as well (Enarson 1998; Fothergill 1999; Tyler and Fairbrother 2013; Enarson et al. 2018; Villarreal and Meyer 2020). However, women are not generally at higher risk, but, more properly, women and men are put differently at risk.

While the vulnerability-led perspective aims to draw proper implications for gender-sensitive disaster relief, it needs to be critically informed by a proper understanding of how gender becomes reality as well. An uncritical claim for equal treatment that implicitly assumes a homogeneous disaster population runs the risk to be gender-blind rather than gender-neutral, neglecting differential needs and exaggerating human suffering (Richter and Flowers 2010). On the other hand, treating women as different but equal (Esping-Andersen 2002; Pateman 2006) risks both a "throwback to biological justifications" (Lorber 1997, 24) of differences and a reductionist view of vulnerability to the mere gender dimension (Fordham 1999; Fothergill 2003; Richter and Flowers 2010; Ross 2012). Recently, Bradshaw (2014) revealed such a tension in disaster risk reduction strategies, which refer to women as "virtuous victims". It presents women as both needy and capable as responsible caregivers, thus appreciates women's competences and strengths, but, at the same time, reinforces their alignment with the reproductive sphere. 


\subsection{Gender Differences in Disaster-Related Activities}

Moreover, disaster scholars have found men and women to undertake different disaster-related activities. Consequently, they started to examine the "gendered terrains of disaster" through both "women's eyes" (Enarson 1998) and "the eyes of men" (Enarson and Pease 2015, 9).

In the aftermath of disasters, women predominantly take charge of the unpaid work in the reproductive sphere (caregiving, daily chores). Obviously, this is deeply anchored in the gender patterns of everyday life, where traditional patterns of labour division within the family persist. Despite women increasingly enter the labour market, they still undertake a major partition of unpaid work (Lewis 2001; Esping-Andersen 2002; Lister 2010). Indeed, disasters bear moments for intrafamily collaboration (Enarson 1998; Fothergill 1999), but families quickly revert to pre-existing patterns of labour division. What is more, women's reproductive work even extends in both quantitative and qualitative terms and becomes more complex, demanding, and expanding (Enarson and Scanlon 1999; Fothergill 1999; Enarson 2001; Fothergill 2003; Reid 2012). This is further exacerbated by the breakdown of infrastructure, such as child-care facilities, public transport, or social networks (Fothergill 1999), which provide institutional support that releases women from their domestic responsibilities (Esping-Andersen 2002). This hampers the compatibility with other responsibilities, and, thus, exacerbates what is well known as the "second shift" (Hochschild and Machung 1990). Consequently, women's paid work often disproportionally decreases in the aftermath of disasters (Enarson and Scanlon 1999; Fothergill 1999; Enarson 2001; Enarson et al. 2018). Their position in the division of paid and unpaid labour shifts towards the latter and they face a mere "role carryover of caregiving in disasters" (Villarreal and Meyer 2020,16).

On the contrary, men's partition of reproductive work is often found to decrease due to their high engagement in occupational emergency work and the community fight against the disaster impacts. Ironically, this often relies on women's "backstage support" (Enarson 1998, 163) as caregivers, householders, etc. (Enarson 1998; Fothergill 1999; Wilson 1999; Enarson 2001). This idea is yet to be found in early feminist's work on the welfare state, which emphasised women's unpaid work in the family as a precondition of men's privileged position in the labour market (Orloff 1993; Mosesdottir 1995; Lewis 1997; Lorber 1997).

This is not to say that women do not contribute to the disaster response through occupational or community work at all. Indeed, they do. However, the labour market is far from being an egalitarian site, but rather characterised by a strong occupational segregation, which Esping-Andersen (2002) used to call "female employment ghettos". While women have rarely been employed in professionalised emergency organisations (Wilson 1999), they largely contribute to the disaster response through traditional "female" jobs, such as nursing, childcare, or education (Enarson 1998; Fothergill 1999; Wilson 1999; Enarson 2001). Yet, these are hardly 
acknowledged as disaster work. Therefore, even women's paid disaster work is rather described as "backstage work" (Enarson 2001, 8). Likewise, voluntary work follows gendered lines, too (Rotolo and Wilson 2007), and lacks female leaders (Erlinghagen et al. 2016). This holds for voluntary disaster work in the community sphere as well: While men are found to engage in technical, practical and physically demanding tasks - the publicly visible fight against disaster impacts -, women rather volunteer in caring and reproductive tasks (Enarson 1998; Fothergill 1999: Enarson 2001). Anyway, "real" emergency work is too often equalised with an active and publicly visible fight against the disaster impacts, which enacts a symbolic dividing line, excluding women's hidden or backstage work from being recognised to conbribute to the disaster recovery (Enarson and Scanlon 1999; Enarson 2001).

Nevertheless, women's contributions are not exclusively restricted to so-called "female" tasks. They engage in their previous roles, but also expand and take on new roles. Actually, women are found to participate in highly visible and so-called "male" tasks as well (Enarson and Scanlon 1999; Fothergill 1999; Wilson 1999; Enarson 2001). E. g. at times, they are employed in professional emergency organisations or emergency relief projects, engage in voluntary emergency organisations and conduct publicly visible and physically demanding tasks, such as - in the case of flooding - sandbagging or dike building. However, the point is, that women have been underrepresented in these tasks and more so in leading positions, their capabilities and perspectives have been neglected (Horton 2012) and their help has often been excluded or denied (Villarreal and Meyer 2020).

\subsection{Disasters as Rupture of Power Relations}

Disasters have also been considered as a rupture of the existing power relations. Often, pre-existing patterns of dependence become exaggerated. The abovementioned shift in the labour division, for example, may exaggerate the economic dependence of women and cement power relations within families (Enarson 1998; Richter and Flowers 2010; Enarson et al. 2018). But disasters may also impose dramatic changes on livelihoods and family relations, push women into autonomous livelihoods, and force women to take on financial responsibility and enter the labour market (Enarson et al. 2018). Indeed, this is hardly a matter of choice, thus, it would be cynical to consider it as true empowerment.

Facing such dramatic circumstances, disaster assistance may relieve disaster victim's pressure of survival (Enarson 1998), particularly for women (Richter and Flowers 2010). However, it may also constitute new lines of dependence, e. g. dependence on the state (Lorber 1997; McIntosh 2006; Pateman 2006). The experience of being dependent, needy, and helpless, may further threaten identities and cause suffering through the subjective experience of blame and stigmatisation (Fothergill 2003). Hence, assistance is an ambiguous term, as it can be both supportive and 
oppressive at the same time (Lister 2010). This requires disaster relief to take on a self-critical perspective in order to preempt negative side-effects.

However, in the midst of the disaster and human suffering, there also lies potential for the experience of solidarity and empowerment. At first glance, disasters can alter unequal power relations within families, which is indicated by cooperation and solidarity, or even by an increase in family conflicts (Enarson and Scanlon 1999; Fothergill 1999). They further provide a fruitful ground for the formation of collective interests and, hence, may trigger the development of grassroot organisations and increase women's political power (Enarson 2001; Enarson et al. 2018). Further, women's abovementioned engagement in visible and physically demanding so-called "male" tasks often provides women with the "pride of taking on the role" (Fothergill 1999, 131) and the experience of being physically competent, autonomous, self-sufficient, assertive or civic-minded (Enarson 1998; Enarson and Scanlon 1999; Fothergill 1999). Such experiences make gender differences visible and may serve as an "'eye-opener' about male power" (Enarson and Scanlon 1999, 116; also Horton 2012).

\subsection{Disasters and Concepts of Masculinity and Femininity}

Moreover, scholars pointed to gender images that inform expectations in the disaster setting. Often, women are assumed to be emotional, sensitive, and passive by their nature, hence determined for caregiving, organisational issues, and emotional care (Bourdieu 2001). In contrast, "real" men are often elided with physical strength, competitiveness, assertion, courage, power, dominance, and control, hence, the opposite of feminine traits (Willer et al. 2013). Such widely-held beliefs constitute a cultural concept of "hegemonic masculinity" (Connell 1987) that describes the "currently most honored way of being a man" (Connell and Messerschmidt 2005, 832), complemented by an "emphasized femininity" (ibid., 848). These inform, how gendered actors are portrayed, perceived and expected to behave in the disaster setting. Women are portrayed as "universal disaster victim - tearful, beleaguered, and overwhelmed" (Enarson and Meyreles 2004, 50) and perceived as "hapless women awaiting strong-armed male rescuers" (Enarson 1998, 158). On the other hand, men are portrayed on the base of the social expectations of masculinity, while subordinated masculinities are often mixed up with images of femininity: "The manliness of men and boys is judged by their ability to measure up to this normative notion" (Enarson and Pease 2015, 7). "Real" men are assumed to actively engage in the disaster fight and take on the role of an heroic rescuer. As this requires the existence of passive and helpless victims, which is largely assigned to women (Enarson and Scanlon 1999; Enarson 2001; Enarson and Meyreles 2004), the relational character of gender concepts becomes obvious (Connell and Messerschmidt 2005). However, what is really going on in disasters does not necessarily adhere to the images and narratives of gender (Scanlon 1998). 
Nevertheless, gender expectations actually inform behavioural patterns and even translate into the institutional arrangements. Tyler and Fairbrother (2013) argued that the Australian response to bushfire is materially and culturally dominated by the hegemonic masculinity, which is characterised by physical strength, risk-taking and a frontier mentality. Further scholars argued that the organisational culture in emergency organisations, such as firefighting services, is strongly shaped by masculine culture, such as authoritative command-and-control structures, quasi-military culture, and a centrality of heavy machinery and technofix attitudes (Enarson and Scanlon 1999; Wilson 1999; Ericson and Mellström 2015; Enarson et al. 2018). Often, men are found to refuse asking for help, which would portray them as needy, incapable, and dependant (Enarson 2001), or are more prone to risk-taking behaviour or the refusal of protective actions, such as evacuation (Tyler and Fairbrother 2013). As outlined by Bradshaw (2015), such a risk-taking behaviour is far away from a simple expression of machism, but rather a result of men's socially imposed responsibility to protect their family and livelihoods.

Recently, Austin (2015) observed the emergence of a "disaster masculinity" in the wake of disasters, referring to Willer et al.'s (2013) idea of "overdoing gender". It depicts the extreme demonstration of masculinity through toughness, courageous behaviour, physical empowerment, or the use of violence. He argues that disasters constitute "crises of masculinity" by rupturing institutional arrangements that underpin the masculine domination. Against this background, the exaggeration of "manliness" purposes to restore masculine status. This sheds new light on the often observed increase in gender violence in the aftermath of disasters as well (Austin 2015; Enarson 2001; Enarson et al. 2018; Rezwana and Pain 2020), which is a matter of power rather than a simple result of emotional stress or substance abuse. Likewise, scholars observed an extreme demonstration of masculinity in the firefighting domain. Eriksen and Waitt (2015), for example, refer to the "ongoing bravado" and the "heroic" action on the "battlefield of firefighting" (ibid., 78) through which male firefighters strive to maintain their masculine identity. Likewise, Pacholok (2013) examined the struggles to redefine the meaning of real firefighters, after the dominant concept of firefighting masculinity had been damaged by the lost fight against the fire, the collaboration with women and inequalities between male firefighters. This motif is related to Bourdieu's (2001) idea that male privilege comes at some cost: "Male privilege is also a trap [...] imposed on every man by the duty to assert his manliness in all circumstances" (ibid., 50). Consequently, situations that threaten masculine identity often compel men to behave courageously, neglecting danger and denying precautionary and safety measures in order to sustain their masculinity.

To sum up, it is a well-known fact that disasters are gendered sites in terms of both vulnerability and activities. Further, it is widely accepted that these differences are informed by the pre-disaster gender order. Indeed, disasters have also been considered to bear moments of deviation from established gender patterns and disrupt 
power relations. This makes it even more important to properly understand, how the gender order is perpetuated in and throughout the disaster. However, the disaster itself has hardly been explicitly addressed as a site for reproduction of gender, with the exception of recent scholars, who refer to the restoration of masculinity. This paper aims to contribute to this gap. As outlined in the following chapter, it takes disasters as frameworks for action that are symbolically shaped by gender expectations and sheds light on how gender is reproduced through the doing of actors.

\section{Disasters as Symbolically Shaped Frameworks of Action}

Today, the notion that both gender and sex are social categories rather than naturally given facts hardly needs to be clarified (Bourdieu 2001). Despite Gaillard et al. (2017) accused disaster research of sticking to a dualistic and naturalistic view on gender, it has been widely accepted in disaster research that gender differences are far away from being determined by a naturally given sex but rather are socially constituted. Still today, socially constituted differences between men and women underpin the social reality and permeate the institutional arrangements of entire societies (certainly, to a varying degree). The dual notion of gender functions as a virtue "warrant of our social arrangements" (Goffman 1977, 302). It structures even basic dimensions such as time and space and constitutes an all-encompassing "gender order" (Flood 2007). Therefore, it still provides analytical heuristics that helps to grasp the realities of socially constituted gendered actors, who have incorporated different behavioural scripts, skills, and resources through their socialisation as men or as women.

However, the established gender order has to be permanently reproduced through the doing of actors. Referring back to West and Zimmerman (1987), the concept of "doing gender" refers to a "complex of socially guided perceptual, interactional, and micropolitical activities that cast particular pursuits as expressions of masculine and feminine 'natures"' (ibid., 126). It overcomes the analytical reduction of gender to individual characteristics and takes it as a relational and processual category. The established gender order is embodied as "gendered scripts" (Goffman 1977), gender "habitus" (Bourdieu 2001), or incorporated "social accounts" (West and Zimmerman 1987). If actors then comply with the order, which they have incorporated, it is both confirmed and legitimised: "If we do gender appropriately, we simultaneously sustain, reproduce, and render legitimate the institutional arrangements that are based on sex category" (West and Zimmerman 1987, 146). If the same patterns further guide the sense-making processes of this order, it becomes disguised and taken-for-granted (Lorber 1994; Bourdieu 2001).

Anyway, if gender is and has to be permanently reproduced by doing, then it can be undone as well. Hirschauer (2001) suggested that the structuring force of the gender category may be neutralised by an indifferent attitude towards gender 
("undoing gender"). This does not mean that gender becomes disguised or dethematised, but rather that it is not activated as a category that structures social action in a given situation.

Considering gender as being what individuals do (or not do) rather than what they are sheds light on the different experiences and activities in the wake of disasters - similar to what disaster scholars used to highlight, but with a slightly different accentuation. Disasters provide "scenes for the performance of genderisms" (Goffman 1977, 325); hence, for doing or undoing gender. But a proper understanding of the nexus of the gender order and the disaster setting not just requires to examine what actors do in a given situation, but also how far gender is assumed to make a difference in the given situation. In this vein, disasters are not just sites for "practically" (un-)doing gender. Rather, actors act and perceive the action of others on the base of their framing of a given situation. These frames may be more or less related to gender expectations (depending on the context), meaning that in certain situations, different ways to (properly) behave, to act, and, actually, to be are assigned to gendered actors. Thus, disasters are symbolically limited frameworks of action, which put forth practices that, in turn, affirm and reinforce the symbolic limitations. To put it in other words: What is going on in disasters is not just shaped by, but also shapes the gender order.

\section{Methodological Considerations: Revisiting a Case Study}

In order to illustrate how the gender order is reproduced in the wake of disasters, the paper revisits a case study on a mudslide disaster in the Austrian Alps in 2012. The purpose of the original study was to reconstruct interpretative patterns (Pfister 2020). Therefore, the study does not claim to draw a holistic picture of the gendered realities. Nevertheless, it entails rich material providing illustration of how gendered actors experienced the disaster site of action and its symbolic limitations.

20 guided interviews were conducted, closely following Ullrich (1999). The interview partners were selected by varying their disaster-related role and socio-economic parameters (see table 1). Each interview started with an open and detailed narration of the personal experience of and actions towards the disaster. Further it addressed the interviewees' explanatory frames and the opinions on an appropriate way of dealing with disasters. While not directly addressing gender-related issues, the interviews, therefore, entail gender-related experiences. Further, when gender-related statements were expressed, they are an expression of the taken-for-granted reality, since they had not been forced by the interviewer.

The verbatim transcripts of the interviews have been analysed closely following the principles of thematic analysis (Braun and Clarke 2006). After reading and re-reading the material (familiarisation) in tandem with the theoretical background, 
Table 1 Interview sample

\begin{tabular}{llc}
\hline Sample size & & 20 \\
\hline Group Belonging & Expert & 5 \\
& Affected persons & 14 \\
& Expert and affected & 1 \\
Within affected persons & Male & 8 \\
Gender & Female & 7 \\
Age & $20-34$ years & 2 \\
& $35-39$ years & 3 \\
& $50-64$ years & 4 \\
Profession & $65+$ years & 6 * \\
& White collar worker & 5 \\
& Blue collar worker & 5 \\
& Self employed/Farmer & 4 \\
& Unemployed/Homemaker & 1 \\
\hline
\end{tabular}

${ }^{*} 65+$ year-olds are overrepresented in the number of inhabitants of the village.

initial ideas of themes have been formulated that served as "sensitizing concepts" (Blumer 1954). Having in mind the gendered allocation of tasks, and concepts of femininity and masculinity, relevant data segments have been identified for a detailed analysis, and the initial themes were differentiated, revised and empirically underpinned. The quotes that are used to exemplify the arguments were translated by the author and assigned acronyms on the base of the most common names in Austria.

Before we turn to the key findings on how gender and gender expectations played a role in the disaster setting and reinforced or tackled established gender patterns, information on the disaster operation and the institutional context is provided on the base of organisational reports, the regional disaster law and official proceedings.

\section{Providing Context: The Austrian Mudslide 2012}

After prolonged and heavy precipitation in 2012, a mudslide buried a small village in Austria. A plenty of homes, farm buildings, agricultural lands and forestry were destroyed, as well as animals were killed and few persons were injured. Estimated private damage exceeded 2 Mio. for the village alone, and the costs for the disaster operation approximated $17 \mathrm{Mio}$. Indeed, on a global scale this might be considered a 
small disaster, if at all, but in Austria it was declared a major disaster and considered a major calamity in the public.

What makes it an interesting case is, for one thing, that in Austria the social order in general and the gender division of labour have been strongly informed by the traditional family model and the idea of a male breadwinner (Esping-Andersen 1990; 1999).

For another thing, women have been almost invisible in the official disaster response network. In Austria, the operational implementation of the disaster response is largely built on both voluntary emergency organisations, such as firefighting and paramedical services (considered the "operational backbone" by the federal crisis management agency), and the military. While data is missing on the female rate during the disaster response in the mudslide disaster, the general female rates in firefighting services and the military show an impressive underrepresentation of women. In 2010 (no detailed figures available for later years), the female rate of active firefighters was at $4.2 \%$ for voluntary services, and at $0.01 \%$ for occupational services (OEBFV 2011). Anyway, formal membership in firefighting services has been allowed for women only in recent decades, and while female member rates are slowly rising, female leaders are still rarely to be found (Horwath 2013). Likewise, female membership is rare in the Austrian military, and accounts for a total number of 612 soldiers in 2018 (Statista 2020).

Anyway, the operational taskforces are subordinated to the disaster authorities in charge. Usually, these are the local or district governors, who function as disaster managers. They are supported by disaster officers and a disaster committee, which consists of invited actors (e.g., emergency services, public agencies, engineers, etc.) and is the focal point of decision-making power in the official disaster operation. Based on the attendance lists on 45 crisis committee meetings during the mudslide disaster operation, the average female rate of the participants was at $0.8 \%$. Thus, women were fairly absent.

\section{Reproducing the Gender Order in the Wake of the Austrian Mudslide}

Having provided some information on the context, we shall now turn to the findings from the interviews on how gender and gender expectations played a role during the mudslide disaster response.

\subsection{Gender-Specific Allocation of Tasks}

First and foremost, women did not solely undertake traditional "female" tasks. Anna (20-34, careworker, affected and voluntary firefighter) is both an affected inhabitant and a voluntary firefighter. She remembers that she fought side by side with her male fellows against the debris jams in the alpine river in the night before 
the mudslide buried the village. Later on, however, she was assigned responsibility for delivering food and organisational issues in the fire department:

Well, I spent each day in the village. I did the catering. I was located in the fire department. Cooking coffee, providing food, looking after the people. When anyone needed anything, I tried to help. (Anna)

Apparently, even at the front line of disaster operation, the allocation of tasks followed gendered lines.

When we turn to the private and the community sphere, both women and men contributed to the disaster response. However, the interviewees largely remember men to have taken on initial action - cleaning-up the debris, helping relatives and neighbors or taking control. Hannah (35-49, teacher, affected) reported: "It was my father-in-law, who said that he wants to start with the clean-up right now. And then, of course, we helped". Other female interviewees remember that "the men already started to clean-up" (Lena, 20-34, white-collar-worker, affected), while they themselves undertook organisational tasks, oversaw the clean-up, or simply were waiting, as they perceived themselves as incapable of doing anything. Sarah $(65+$, housewife, affected), for example, reported to have opted in as late as mud and debris had been removed:

Approximately after a week, we were able to come here. I started to wipe off the interior, while the military personnel cleaned up the cellar. [...] Finally, my sister-in-law arrived in order to help us. And my other sisters-in-law as well. They helped us cleaning the house. [...] well, we were not able to do anything, while they were cleaning up the debris. After that, we began to drain the cellar. And then we had to wipe off the mud. [...] This is the moment, when your work begins. [...] This is the work that you can conduct. You may go through the house for ten times and wipe it off each day. (Sarah)

In contrast, carework largely fell to women. Strikingly, female interviewees more often reported that looking after their children and elderly dependents was the first thing, they thought about: "I thought, 'I have to go downstairs to my mother!' Then I went there quickly and heard her screaming" (Sophie, 50-64, blue-collar-worker, affected). And further: "She was sitting in the chair. She was shocked. I helped her putting on her clothes. She was incapable of doing so". Similarly, Hannah only thought about her children in the immediate aftermath: "At that moment, I was scared ... Where are my children? When I did recognise them to be safe, I was reassured" (Hannah). This is not to say that male actors did not worry about their families and relatives, but the point is, that these themes predominantly emerged in women's narratives.

Moreover, women were put in the center of narratives about emotionally comforting and hosting others. Even when families provided shelter for the affected persons, the female family members served as reference point to remember emotional 
comfort. For example, Sarah, who was sheltered by the parents-in-law of her son, assigned the positive effect on her well-being to the female part of the couple: "To stay with her cheered me up. To be not alone..." (Sarah). Similarly, Hannah and her husband gave shelter to some relatives, but she remembers that it was her, who took care of children and others, and spent emotional recovery:

I stayed at home. Hence, I was able to look after the children and the people. [...] They were able to cope with what had happened... To speak about it... Grandfather told me, how afraid he had been. [...] They were able to talk to me and I was there to listen to them. (Hannah)

Furthermore, catering for the disaster responders was considered a female task. David (35-49, social worker, expert) referred to a mere "women's initiative", that met up to comfort each other, prepare meals, bake cake and provide the emergency responders with snacks. Likewise, Emma (50-64, careworker, affected) reported that she catered for her relatives and neighbours. Further, she remembers masses of cakes and snacks being donated by women:

There were masses of donations... There were so many women, who baked cakes and provided snacks. And then they organised a movie night, where they supplied all these masses of drinks and pastries. (Emma)

Providing food is strongly informed by the need to give something back, or what one might term the reciprocity of disaster relief. And, even in non-disaster times, the reproduction of a family's social and symbolic capital is assigned to women (Bourdieu 2001). Julia explained (50-64, farmer, affected):

Well, you want to give something back. You are grateful to have someone to help. Since this assistance is for free, you want to give them at least something warm to eat. (Julia)

Further, organisational and administrative tasks were largely conducted by women. For example, Emma reported that it was her and her daughter who went to the disaster authorities to request a drive-thru allowance. Likewise, Lena told that she and her mother took charge of the registration of the survivors, while her father and her husband were already digging mud:

The men already started to work. We had to register at the municipality, notify that we are alive. And my mother and I drove there. (Lena)

Sophie reported that her male family members already returned to the disaster are, while she was organising the household in their shelter:

Then they told us, we have to come here, since the military wants to enter the house in order to clean up the cellar. Thus, my husband and my son quickly drove here. But since we were relocating due to the evacuation, I 
told them that I have to tidy up and organise the household and will come later. (Sophie)

Obviously, the disaster narratives link women to a plenty of tasks in the disaster response. However, they are hardly recognised as such. For example, Emma felt like she had not contributed to the recovery at all due to her health status, although she was highly engaged in catering and comforting others:

I had back pain. Hence, I was not able to help in the recovery process. But I was able to use our firewood stove and cook for the people. I guess, I kept running the catering [laughs]. They came for eating. I tried to help, wherever I could. (Emma)

Likewise, when Lena referred to her and her mother's tasks, an implicit symbolic hierarchy of recovery tasks emerged:

We packed our stuff and valuable goods - you know, in case of looting. We helped... Well, actually, it was not to help in the clean-up operations... But to cater for the people, who helped. (Lena)

This reflects what was termed in the literature as the hidden or background disaster work of women, which often fails to be fully recognised.

\subsection{Concepts of Femininity and Masculinity as Guiding Principles}

Apparently, the gendered lines of disaster-related activities are guided by concepts of femininity and masculinity. The point is, however, that ideas of what is proper for men and women not just bring into being actions or memories that are in line with these ideas, but, in doing so, practically affirm and reinforce these ideas. This is most clearly expressed by Sophie, who regrets that she could not oversee the clean-up of her property:

It was important for me that they are sensitive about valuable things when doing the clean-up. [...] Finally, I could not oversee it. They cleaned up the cellar and disposed everything [deep breathe]. I'm a little bit upset about that. Once more, I realised that WOMEN are much more diligent and accurate. (Sophie)

At some points, interviewees referred to passive, incapable, and needy victims. When they did so, it were women, old men, or little boys - obviously characters, that do not fit the idea of masculinity. Maximilian (65+, farmer, affected) remembers: "The WOMEN were FRIGHTENED. They stood there and cried and moaned and prayed: Please, don't let this happen again" (Maximilian). Others referred to women as being shocked, standing in the way, or being incapable of doing anything. And when David reflected on the limits of informal volunteers, he referred to women 
(and boys) as the opposite to the professional rescue workers, who comply with the concept of masculinity:

There might be three or four women and some boys. They would be totally burnt out after two hours. They are not used to that. Unlike emergency responders, whom I assume to be capable of that. (David)

The assumed helplessness and emotionality of women further required men to protect them - even from handling the truth. Lena remembers quite well, when her husband and others avoided to hurt her with the truth about her dying animals:

I heard that they found an animal that was still alive. Then I started to ask. Because there had not been many of them. Then, they had to tell me. But in the beginning... I recognised... It was a kind of... "Go inside, let us deal with it, it's okay!" They simply sent me away. (Lena)

Likewise, David deprived his wife of information about further danger to their property and lives, trying to protect her from an inconvenient truth: "I had access to information. Even myself was not able to sleep at night. I did not tell it my wife. She would not have stayed in the house any longer" (David).

In contrast, it were largely men, who were remembered as active force in fighting against the disaster and as "one-dimensional 'rescuers" (Enarson and Scanlon 1999, 106). Lena, for example, reported that she was totally upset and lacked any orientation during the impact period, while she perceived her husband as capable and taking on control in the situation: "But my husband took on the role of the protector. He told us: Go up there, up there" (Lena). Further, the predominance of firefighters and the military was pervasive in the interviews: Each interviewee referred to them as the core of the disaster operation in a taken-for-granted manner. Not just are these services materially dominated by men (see chapter 5), but, as argued, also shaped by masculine culture. They are assumed to be physically strong, emotional stable, and capable. This is clearly expressed by Hannah, who highlights the advantages of the military:

Civilians actually try to help, but they become tired at some point. And then it is great to have military troops, whom you can send there and tell them to dig mud and they are digging for the whole day. (Hannah)

Likewise, David reflected on how men fit the demands that come with emergency work:

They face restrictions in family-life. When a male firefighter has to get up in the middle of the night, no one asks him, if he wants to do so or if his wife is moaning: Oh no, he's leaving again and again. (David) 
Further, what was termed "disaster masculinity" (Austin 2015) emerged with evacuation behaviour. Interviewees remember that some residents refused to be evacuated and secretly stayed overnight in the restricted area. When they referred to such behaviour in more detail, they referred to men. Anna's father, for example, denied evacuation in order to protect their property from looting:

I must confess that my father stayed in our house for one night. He said, some people sneaked around and I'm sure that a plenty of stuff had been stolen. (Anna)

Similarly, Maximilian, an old farmer, justified his refusal to leave the area by highlighting the responsibility to care for his cattle:

I told them, I will not leave [...]. We will stay here. Where should we have gone with our cattle? When they told me that I might die, I always responded: I will die together with my cattle. (Maximilian)

Eventually, the point is not so much the allocation of tasks itself, but rather the allocation of tasks along with ideas of female or male tasks. While this becomes apparent at many points, it is striking, when tasks are explicitly declared women's tasks, largely because women are considered more appropriate for their conduct due to their "female nature". Likewise, the question is raised, if women simply do not conduct "male" tasks, because they lack physical strength. Indeed, the active disaster fight is often physically demanding and therefore one shall not neglect the material body. But the point is, that physical strength is elided with gender categories. A sufficient physical performance for these demanding tasks is expected from men but not from women, elderly, and young boys, even though the former constitute a heterogeneous group as well. In other words: The question of capability is judged through the lens of gender, rather than by the characteristics of individual bodies. Thus, it is far away from being an allocation of tasks along with individual capabilities, but rather along the belonging to gender categories. As a consequence, resultant practices are not just in line with gender expectations, but also affirm and reinforce these ideas.

\subsection{Undoing Gender in the Wake of Disasters?}

As mentioned in the beginning, women not just acted in accordance with traditional gender expectations. Indeed, the mudslide disaster beard moments, where women deviated from gender expectations and, for example, engaged in the physically demanding disaster fight as well. This alone bears empowering potential and provides evidence that gender does not necessarily make a difference in the disaster situation. Anna, the female firefighter, reflects on her experience: "Well, one often faces barriers as a woman. But ... It makes one STRONGER ... To complete tasks and that everyone knows you and relies on you" (Anna). Taking action has the potential to 
alter ones self-concept, to experience oneself as active and competent and release oneself form the incorporated social expectations.

However, the mere conduct of activities beyond traditional gender lines does not necessarily relieve them from the symbolic limitations imposed by gender expectations. In other words: Undoing gender is more than deviation from the expectations imposed on gendered actors. Often, practically "deviant" women are perceived as insufficient, or their performance is appreciated for its compliance with masculine criteria. A quite impressive example is given by Anna, the female firefighter, who was sent to an affected building in order to assess the damage and the demand for relief, when she was asked to be replaced by a male firefighter, who is capable of male tasks:

Well... Of course, in such situations, you are disadvantaged as a WOMAN. [Interviewer: In how far?] They often say, they'd need MEN to pitch in. [...] We faced such a situation. They said they'd need a man. Anyway, this situation was weird. The cellar was flooded and full of mud and we were there to have a look on it. And a MAN should have done this [laughs]. (Anna)

Accordingly, undoing gender is not a sole question of what gendered actors do, but rather if gender ceases to symbolically limit the framework for action in a given situation. It not just requires to deviate from established gender patterns, but to think and act as if gender would not matter in the given situation. This does not mean that gender necessarily becomes disguised or de-thematised. In the abovementioned example, Anna further reports:

Well, I did smile over that, since men cannot do anything more than women.

[...] What would have a man done other than me? [...] I remember it quite well [laughs], when they said: They need a MAN, although we were women and we were there. (Anna)

The potential for undoing gender lies not so much in the mere conduct of a "male" task, but rather in Anna's gender-neutral attitude towards the situation. Although one shall critically mind the taken-for-granted way in which she refers to a dualistic concept of gender, in her view, gender simply makes no difference in the conduct of tasks, but rather the individual capabilities of an actor.

\section{Discussion}

What is going on in disasters is not just shaped by, but also shapes the gender order in manifold ways. Disasters make visible social structures. In this vein, gender differences in the disaster situation are understood against the background of the established gender order. However, the story does not end at this point and the perpetuation of the gender order needs a proper understanding. This paper suggested disasters to 
be symbolically shaped frameworks of action, hence, as sites for the reproduction of gender. It further illustrated, how gender is reproduced in the wake of disasters, by revisiting a previous case study of a mudslide disaster.

The findings are in line with previous studies, which suggest that the allocation of gender-related tasks follow gendered lines. Both men and women contributed to the disaster response. While the former were engaged in an "active disaster fight", the latter predominantly took charge of what was discussed in the literature as hidden "backstage work" (Enarson 2001). This allocation of tasks is far away from being a result of the actual capabilities of individuals. Rather, certain tasks are elided with concepts of femininity or masculinity. These ideas are not necessarily an outcome of what men and women actually are, but rather what they are supposed to be. Hence, they serve as lenses to perceive reality. Nevertheless, disaster situations also bear opportunities to deviate from gender expectations, as previous scholars have suggested as well. Indeed, acting beyond these symbolic barriers alone may bear empowering potential (self-experience, gain skills, etc.). However, it is not sufficient for undoing gender, meaning that gender ceases to matter in certain situations.

This paper suggests to put stronger emphasis on the disaster as site of reproduction of established gender patterns. The point is that the doing of actors within frameworks of action that are symbolically shaped by gender expectations puts forth practices that affirm and reinforce these expectations. Certain practices in the wake of disasters are not just informed by the previous gender order, but, by being in line with it, produce its own affirmation. The abovementioned allocation and perception (or remembrance) of tasks - men tend to undertake highly visible and recognised disaster work, while women conduct backstage tasks - reinforce ideas that underpin the masculine domination, namely that men "perform all the brief, dangerous and spectacular acts which [...] mark breaks in the ordinary course of life" (Bourdieu 2001, 30), while women "are assigned [...] the tasks that are private and hidden, even invisible or shameful" (ibid.).

This is the reason, why it is not enough to merely focus on the allocation of tasks without referring to their symbolic guise. Deviating from previous gender expectations alone may not be sufficient to undo gender. Acting beyond the gender expectations that are imposed on the actors does not necessarily relieve women and men from the pressure imposed by these gender expectations: They may face resistance or find themselves in a "double-bind" (Bourdieu 2001, 67), meaning that women (men) either meet masculine (feminine) criteria and are judged insufficient by feminine (masculine) criteria, or behave like women (men) and are judged unsuitable for male (female) tasks.

The established gender patterns incorporated by actors serve as deeply anchored principles of acting, thinking, and perceiving the world. Therefore, a simple deviation does not cease gender to make a difference. As long as a gendered actor, who acts beyond gendered expectations, is perceived as an actor, who does not comply 
with gendered expectations, rather than an actor, who just acts in the given situation according to his or her capacity (meaning that the situation is gender-neutral), gender continues to matter. Therefore, disasters may serve as opportunities for new experiences and deviation from the established order, but they do not necessarily blur the gender-related boundaries of the symbolically limited space of action. In other words: The reproduction of gender patterns is related to incorporated patterns of acting and thinking, and as long as crises in practices are not accompanied by crises of thinking, they will not result in profound change (Bourdieu 2001). The question is then not that much about the extent to which an actor's doing is in compliance or contradiction with gendered expectations, but rather to what extent this doing is gender-neutral.

Finally, it is important to point to some limitations of the study. Firstly, the gender-related experiences of the disaster are reconstructed on the base of narratives four years after the disaster had happened. Thus, the study cannot tell anything about what women and men actually did and perceived in the wake of the disaster, but rather is limited to what lasted in their memories. Most likely, their memories are distorted by socially shared expectations as well. Indeed, distorted remembrance itself is a powerful mechanism to reproduce a social order (Dimbath and Wehling 2011). Nevertheless, further research is needed to examine what actually happens in a disaster, e. g., by participating observations, in order to find out when and how the potential for undoing gender emerges and is passed over.

What is more, the mechanisms to reproduce the gender order in the wake of disasters have to be related to both the broader societal context and the situational context. The former refers to the need for comparative studies between different gender regimes. Disasters may, for example, provide more opportunities to actually undo gender, if the context is already fluent or underpinned by ideas of gender equality. The latter refers to the need to compare different disaster types, meaning that different disaster types may open spaces that are accompanied by varying gender expectations. Comparing technical and natural disasters, Villarreal et al. (2020) argued that there might be more similarity of the disaster experience across women than difference across the disaster types. However, research is needed on how the gender order is reproduced or even transformed in certain disaster situations that may provide a stage for women to become more visible. Scanlon et al. (2009), for example, showed for the Canadian Response to the Spanish Flu that women became the main voluntary responders. Likewise, women employed in traditional "female employment ghettos" (Esping-Andersen 2002), such as nurses or cashiers, became highly visible in public debates and appreciated as the heroes of the moments upholding the social system at the outset of the current corona crisis.

Eventually, it is not so much the story of assigning the same tasks across gendered actors. Neither is disaster work an emancipatory force in itself, nor is it a rosy set of activities but rather often physically and mentally demanding and put- 
ting actors at risk. Rather, it is a question of recognition and valorisation of tasks in relation to a perceived problem of action. Likewise to early feminist's struggles to expand the conceptual boundaries of work (e. g., Lewis 1997; Lister 2010), the symbolic boundaries of disaster work need to be expanded in order to recognise the full scope of contributions and dismantling it from its gendered ascriptions.

\section{$8 \quad$ References}

Always, Joan and Kenneth J. Smith. 1998. Back to Normal: Gender and Disaster. Symbolic Interaction 21(2): 175-95.

Austin, Duke W. 2015. Hyper-Masculinity and Disaster. The Reconstruction of Hegemonic Masculinity in the Wake of Calamity. Pp. 45-55 in Men, Masculinities and Disaster, edited by E. Enarson and B. Pease. New York: Routledge.

Blumer, Herbert. 1954. What Is Wrong with Social Research. American Sociological Review 19(1): 3-10.

Boin, Arjen, Paul 't Hart, and Allan McConnell. 2009. Crisis Exploitation. Political and Policy Impacts of Framing Contests. Journal of European Public Policy 16(1): 81-106.

Bourdieu, Pierre. 2001. Masculine Domination. Stanford: Stanford University Press.

Bradshaw, Sarah. 2014. Engendering Development and Disasters. Disasters 39(1): 54-75.

Bradshaw, Sarah. 2015. Rereading Gender and Patriarchy through a "Lense of Masculinity". The "Known" Story and New Narratives from Post-Mitch Nicaragua. Pp. 56-65 in Men, Masculinities and Disaster, edited by E. Enarson and B. Pease. New York: Routledge.

Braun, Virginia and Victoria Clarke. 2006. Using Thematic Analysis in Psychology. Qualitative Research in Psychology 3: 77-101.

Clausen, Lars. 1994. Krasser sozialer Wandel. Wiesbaden: Springer Fachmedien.

Connell, Raewyn W. 1987. Gender and Power. Cambridge: Polity Press.

Connell, Raewyn W. and James W. Messerschmidt. 2005. Hegemonic Masculinity. Rethinking the Concept. Gender and Society 19(4): 829-859.

Dimbath, Oliver and Peter Wehling. 2011. Soziologie des Vergessens. Konturen, Themen und Perspektiven. Pp. 7-34 in Soziologie des Vergessens. Theoretische Zugänge und empirische Forschungsfelder, edited by Dimbath, Oliver and Peter Wehling. Konstanz: UVK Verlagsgesellschaft.

Dombrowsky, Wolf R. 1989. Katastrophe und Katastrophenschutz. Eine soziologische Analyse. Wiesbaden: Deutscher Universitätsverlag.

Enarson, Elaine. 1998. Through Women's Eyes. A Gendered Research Agenda for Disaster Social Science. Disasters 22(2): 157-73.

Enarson, Elaine. 2001. What Women Do: Gendered Labor in the Red River Valley Flood. Environmental Hazards 3: 1-18.

Enarson, Elaine. 11.06.2006. Women and Girls Last? Averting the Second Post-Katrina Disaster. in SSCR. https://items.ssrc.org/understanding-katrina/women-and-girls-last-averting-the-secondpost-katrina-disaster (29.05.2020).

Enarson, Elaine and Joseph Scanlon. 1999. Gender Patterns in Flood Evacuation. A Case Study in Canada’s Red River Valley. Applied Behavioral Science Review 7(2): 103-124.

Enarson, Elaine and Lourdes Meyreles. 2004. International Perspectives on Gender and Disaster: Differences and Possibilities. International Journal of Sociology and Social Policy 24(10/11): 49-94. 
Enarson, Elaine and Brenda Phillips. 2008. Invitation to a New Feminist Disaster Sociology. Integrating Feminist Theory and Methods. Pp. 41-74 in Women and Disasters. From Theory to Practice, edited by B. D. Phillips and B. H. Morrow. Xlibris.

Enarson, Elaine and Bob Pease. 2015. The Gendered Terrain of Disaster. Thinking about Men and Masculinities. Pp. 3-20 in Men, Masculinities and Disaster, edited by E. Enarson and B. Pease. New York: Routledge.

Enarson, Elaine, Alice Fothergill, and Lori Peek. 2018. Gender and Disaster. Foundations and New Directions for Research and Practice. Pp. 205-223 in Handbook of Disaster Research, edited by H. Rodriguez, W. Donner, and J. E. Trainor. Cham: Springer International Publishing.

Ericson, Mathias and Ulf Mellström. 2015. Firefighters, Technology and Masculinity in the MicroManagement of Disasters. Swedish Examples. Pp. 165-174 in Men, Masculinities and Disaster, edited by E. Enarson and B. Pease. New York: Routledge.

Eriksen, Christine and Gordon Waitt. 2015. Men, Masculinities and Wildfire. Embodied Resistance and Rupture. Pp. 69-80 in Men, Masculinities and Disaster, edited by E. Enarson and B. Pease. New York: Routledge.

Erlinghagen, Marcel, Saka Belit, and Ina Steffentorweihen. 2016. Führungspositionen im Ehrenamt ein weiterer Bereich der Benachteiligung von Frauen? Kölner Zeitschrift für Soziologie und Sozialpsychologie 68: 647-673.

Esping-Andersen, Gøsta. 1990. The Three Worlds of Welfare Capitalism. Cambridge: Polity Press.

Esping-Andersen, Gøsta. 1999. Social Foundations of Postindustrial Economies. New York: Oxford University Press.

Esping-Andersen, Gøsta. 2002. A New Gender Contract. Pp. 68-95 in Why We Need A New Welfare State, edited by G. Esping-Andersen. Oxford: Oxford University Press.

Flood, Michael. 2007. Gender Order. Pp. 235-236 in International Encyclopedia of Men and Masculinities, edited by Mi. Flood, J. K. Gardiner, B. Pease, and K. Pringle. London: Routledge.

Fordham, Maureen. 1999. The Intersection of Gender and Social Class in Disaster: Balancing Resilience and Vulnerability. International Journal of Mass Emergencies and Disasters 17(1): 15-36.

Fothergill, Alice. 1998. The Neglect of Gender in Disaster Work: An Overview of the Literature. Pp. 11-26 in The Gendered Terrain of Disaster. Through Women's Eyes, edited by E. Enarson and B. H. Morrow. Westport: Praeger Publishers.

Fothergill, Alice. 1999. Women's Roles in a Disaster. Applied Behavioral Science Review 7(2): 125-143.

Fothergill, Alice. 2003. The Stigma of Charity. Gender, Class, and Disaster Assistance. The Sociological Quarterly 44(4): 659-680.

Gaillard, Jean-Christophe, Kristinne Sanz, Benigno C. Balgos, Soledad Natalia M. Dalisay, Andrew Gormann-Murray, Fagalua Smith and Vaito Toelupe. 2017. Beyond Men and Women: A Critical Perspective on Gender and Disaster. Disasters 41(3): 429-447.

Gilbert, Claude. 1998. Studying Disaster. Changes in the main conceptual tools. Pp. 11-18 in What is a disaster? Perspectives on the question, edited by Enrico L. Quarantelli. London: Routledge.

Goffman, Erving. 1977. The Arrangement Between the Sexes. Theory and Society 4(3): 301-331.

Hirschauer, Stefan. 2001. Das Vergessen des Geschlechts. Zur Praxeologie einer Kategorie sozialer Ordnung. Pp. 208-235 in Geschlechtersoziologie, edited by B. Heintz. Wiesbaden: Westdeutscher Verlag.

Hochschild, Arlie Russell and Anne Machung. 1990. The Second Shift. New York: Avon Books.

Horton, Lynn. 2012. After the Earthquake: Gender Inequality and Transformation in Post-Disaster Haiti. Gender \& Development 20(2): 295-308.

Horwath, Ilona. 2013. Gleichstellung im Feuerwehrwesen. "Gut Wehr!» und die HeldInnen von heute. Wiesbaden: Springer VS. 
Lewis, Jane. 1997. Gender and Welfare Regimes. Further Thoughts. Social Politics. Studies in Gender, State and Society 4(2): 160-177.

Lewis, Jane. 2001. The Decline of the Male Breadwinner Model. Implications for Work and Care. Social Politics. Studies in Gender, State and Society 8(2): 152-169.

Lister, Ruth. 2010. Understanding Theories and Concepts in Social Policy. Bristol: Policy Press.

Lorber, Judith. 1994. Paradoxes of Gender. New Haven: Yale University Press.

Lorber, Judith. 1997. The Variety of Feminisms and Their Contribution to Gender Equality. Oldenburger Universitätsreden 97.

McIntosh, Mary. 2006. Feminism and Social Policy. Pp. 120-133 in The Welfare State Reader, edited by C. Pierson and F. G. Castles. Cambridge: Polity Press.

Mosesdottir, Lilja. 1995. The State and the Egalitarian, Ecclestical and Liberal Regimes of Gender Relations. The British Journal of Sociology 46(4): 623-642.

Neumayer, Eric and Thomas Plümper. 2007. The Gendered Nature of Natural Disasters: The Impact of Catastrophic Events on the Gender Gap in Life Expectancy, 1981-2002. Annals of the Association of American Geographers 97(3): 551-566.

OEBFV (Österreichischer Bundesfeuerwehrverband). 2011. Statistik des OEBFV, https://www.bundesfeuerwehrverband.at/wp-content/uploads/2017/08/Statistik_2010.pdf (29.05.2020).

Orloff, Ann Shola. 1993. Gender and The Social Rights of Citizenship. The Comparative Analysis of Gender Relations and Welfare States. American Sociological Review 58(3): 303-328.

Orloff, Ann Shola. 2009. Gendering the Comparative Analysis of Welfare States. An Unfinished Agenda. Sociological Theory 27(3): 317-343.

Oxfam. 2005. The Tsunami's Impact on Women, https://oxfamilibrary.openrepository.com/bitstream/ handle/10546/115038/bn-tsunami-impact-on-women-250305-en.pdf (29.05.2020).

Pacholok, Shelley. 2013. Into the Fire. Disaster and the Remaking of Gender. Toronto: University of Toronto Press.

Pateman, Carole. 2006. The Patriarchal Welfare State. Pp. 134-151 in The Welfare State Reader, edited by C. Pierson and F. G. Castles. Polity Press.

Pelling, Mark and Kathleen Dill. 2010. Disaster Politics. Tipping Points for Change in the Adaptation of Sociopolitical Regimes. Progress in Human Geography 34(1): 21-37.

Pfister, Sandra. 2020. Jenseits der Sicherheit. Deutungsmuster der Katastrophe und ihre Institutionalisierung im Katastrophenschutz. Bielefeld: Transcript.

Quarantelli, Enrico L. (ed.). 1998. What Is a Disaster? Perspectives on the Question. London: Routledge.

Quarantelli, Enrico L. 2003. Auf Desaster bezogenes soziales Verhalten. Eine Zusammenfassung der Forschungsbefunde von fünfzig Jahren. Pp. 25-33 in Entsetzliche soziale Prozesse. Theorie und Empirie der Katastrophe, edited by L. Clausen, E. M. Geenen, and E. Macamo. Münster: Lit Verlag.

Reid, Megan. 2012. Mothering After a Disaster. The Experiences of Black Single Mothers Displaced by Hurricane Katrina. Pp. 105-117 in The Women of Katrina. How Gender, Race, and Class Matter in an American Disaster, edited by E. David and E. Enarson. Nashville: Vanderbilt University Press.

Rezwana, Nahid and Rachel Pain. 2020. Gender-Based Violence Before, during and after Cyclones: Slow Violence and Layered Disasters. Disasters. DOI: doi.org/10.1111/disa.12441.

Richter, Roxane and Thomas Flowers. 2010. Gender-Aware Disaster Care. Issues and Interventions in Supplies, Services, Traige and Treatment. International Journal of Mass Emergencies and Disasters 28(2): 207-225.

Ross, Lorretta J. 2012. A Feminist Perspective on Katrina. Pp. 15-23 in The Women of Katrina. How Gender, Race, and Class Matter in an American Disaster, edited by E. David and E. Enarson. Nashville: Vanderbilt University Press. 
Rotolo, Thomas and John Wilson. 2007. Sex Segregation in Volunteer Work. The Sociological Quarterly 48: 559-585.

Scanlon, Joseph. 1998. Myths of Male and Military Superiority. Fictional Accounts of the 1917 Halifax Explosion. English Studies in Canada 24(4): 387-411.

Scanlon, Joseph, Casey Hurrell, and Terry McMahon. 2009. Almost Only Women: Canadian Volunteer Response to the 1918-1920 Pandemic. American Journal of Disaster Medicine 4(6): 331-343.

Stallings, Robert A. 1998. Disaster and the Theory of Social Order. Pp. 127-145 in What is a disaster? Perspectives on the question, edited by E. L. Quarantelli. London: Routledge.

Statista. 2020. Anzahl der Soldatinnen im Österreichischen Bundesheer von 1998 bis 2018, https:// de.statista.com/statistik/daten/studie/295745/umfrage/soldatinnen-im-oesterreichischenbundesheer/\#professional (29.05.2020).

Tierney, Kathleen. 2012. Critical Disjunctures. Disaster Research, Social Inequality, Gender, and Hurricane Katrina. Pp. 245-258 in The Women of Katrina. How Gender, Race, and Class Matter in an American Disaster, edited by E. David and E. Enarson. Nashville: Vanderbilt University Press.

Tierney, Kathleen. 2019. Disasters. A Sociological Approach. Newark: Polity Press.

Tyler, Meagan and Peter Fairbrother. 2013. Bushfires Are "men's Business": The Importance of Gender and Rural Hegemonic Masculinity. Journal of Rural Studies 30: 110-119.

Ullrich, Carsten. 1999. Deutungsmusteranalyse und diskursives Interview. Zeitschrift für Soziologie 28(6): 429-447.

Villarreal, Melissa, and Michelle A. Meyer. 2020. Women's Experiences Across Disasters: A Study of Two Towns in Texas, United States. Disasters 44(2): 285-306.

West, Candace and Don H. Zimmerman. 1987. Doing Gender. Gender and Society 1(2): 125-151.

Willer, Robb, Christabel L. Rogalin, Bridget Conlon, and Michael T. Wojnowicz. 2013. Overdoing Gender: A Test of the Masculine Overcompensation Thesis. American Journal of Sociology 118(4): $980-1022$.

Wilson, Jennifer. 1999. Professionalization and Gender in Local Emergency Management. International Journal of Mass Emergencies and Disasters 17(1): 111-122. 


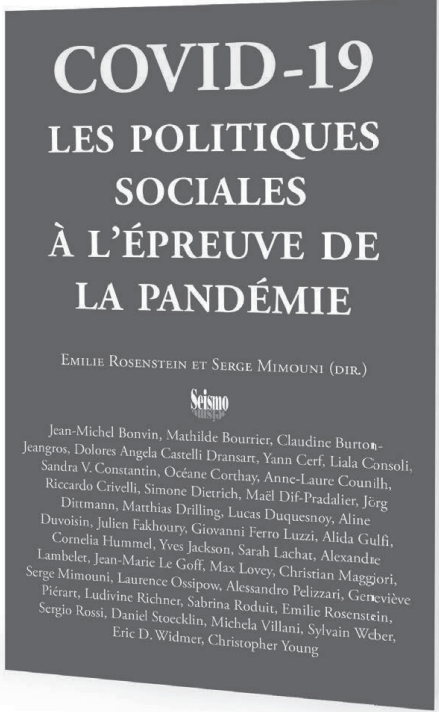

Emilie Rosenstein, Serge Mimouni (dir.)

\section{COVID-19}

Les politiques sociales à l'épreuve de la pandémie

ISBN 978-2-88351-107-1

env. 444 pages, $13.0 \times 22.0 \mathrm{~cm}$

Fr. 38.- / Euro 33.-
Éditions Seismo

Sciences sociales et questions de société
Quel est l'impact social de la pandémie de COVID-19? Quelles tendances se dessinent à moyen et long terme? Quelles sont les réponses apportées face à la crise et quelles leçons en tirer pour les politiques sociales de demain? Cet ouvrage rassemble des recherches clés en sciences sociales ainsi que des entretiens menés auprès de responsables de l'action sociale et sanitaire et d'équipes de recherche. Autant d'analyses qui témoignent des actions et initiatives déployées à travers la Suisse pour appréhender la pandémie.

\section{«La crise de la COVID-19 révèle l'ampleur des inégalités socio- économiques en Suisse. Rarement un ouvrage collectif donne autant envie d'avancer dans sa lecture. »}

Philippe Warin, Université Grenoble Alpes, CNRS, Science Po Grenoble

Emilie Rosenstein est professeure à la Haute école de travail social et de la santé Lausanne (HETSL | HESSO) et chercheuse associée à l'Université de Genève. Spécialisée dans l'étude des politiques sociales et des précarités, ses travaux portent sur l'insertion professionnelle des publics vulnérables, en particulier dans les domaines du handicap et de la jeunesse.

Serge Mimouni est Directeur du Département de la cohésion sociale et de la solidarité de la Ville de Genève. Il a piloté la réponse à l'urgence sociale générée par la pandémie de COVID-19. Diplômé en sciences politiques (IHEID) et en économie (LSE), il enseigne les politiques sociales à l'Université de Genève et à la HES-SO. 